\title{
Processing of Complex Materials in the Copper Industry: Challenges and Opportunities Ahead
}

\author{
GERARDO ALVEAR FLORES (1), ${ }^{1,4}$ CARLOS RISOPATRON, ${ }^{2}$ \\ and JOE PEASE ${ }^{3}$ \\ 1.-Independent Consultant, Hamburg, Germany. 2.-International Copper Study \\ Group, ICSG, Lisbon, Portugal. 3.-Mineralis Consultants, Brisbane, QLD, Australia. \\ 4.-e-mail: galvear1963@hotmail.com
}

\begin{abstract}
With the gradual decrease in the grade of copper ores being processed, copper concentrates have become more complex with higher impurity and gangue content. This trend has had a detrimental effect on smelters as they have to increase throughput to maintain copper metal production, while increasing operating costs due to processing the increased amounts of secondary products (slag, acid) and stabilizing waste streams. This paper discusses impacts from the increased complexity of resources from mine to smelters, highlighting the need for an integrated processing approach to achieve sustainable and competitive multi-metal recovery.
\end{abstract}

\section{INTRODUCTION}

Processing of complex materials in non-ferrous smelting has traditionally been approached as a niche opportunity to capture the economic value contained in the mining resources. Depending on the nature and complexity of the resources, miners have sometimes adopted processing options at the mine site, such as ultra-fine grinding, alternative flotation circuits, or hydrometallurgical processes, to reduce the concentration of elements that would reduce the value of their product. Meanwhile, their customers, the smelters, addressed complexity either by developing new processes or by modifying operating conditions to enhance the removal of deleterious elements. In some cases, synergies and cooperation between base metal processing facilities have improved recovery and waste management. However, in most cases, the copper industry has used dilution as the main response, either by blending of complex materials in central facilities or by diluting small quantities in large feed streams to smelters.

Copper is recognized a cornerstone element to support the move towards a more sustainable society with eco-efficient living standards, e-mobility, efficient house designs, environmentallyfriendly public spaces, transportation designs, and medical applications to reduce disease transmission.
At the time of writing, the global economy faces an unprecedented shock from the impact of coronavirus which has reduced copper demand and prices. This will change as global stimulus and infrastructure programs lift the economy, and this will be an opportunity to stress the positive aspects of copper, not only in the traditional applications of infrastructure but also in less widespread applications in hospitals and public spaces to reduce the risk of disease transmission.

It is therefore essential that the copper industry prepares itself by getting a clear understanding of future supply volume and resource quality. If we face increased copper demand, we need to understand the expected complexity in supply and how this will impact processing facilities in terms of recoveries, product quality, and waste management. This analysis should also consider the increasing pressure to process urban mining resources in existing industrial facilities, since these resources will bring additional complexity that will impact business performance.

\section{UNDERSTANDING THE SUPPLY}

\section{Trends Affecting Copper Mines}

Table I shows a list of identified trends in the copper industry in recent years. ${ }^{1}$ It identifies challenges from: 


\section{Table I. Challenges for copper miners}

\section{Challenge}

Resource complexity and regulatory pressures

Increase in impurity content

Global bottleneck in recycled copper raw materials in 2018

Impurity solution via market mechanisms? Only blending works

Energy

Water

\section{Existing operations}

New mines and plants more complex, deeper and more expensive with lower-ore grades More complex and finer-sized copper concentrates

Opportunity to recover valuable by-products

Limited expansion in operational mines and new mine capacity constraint 2018-2024

Large amounts of mineral waste can pose threats to public perceptions of health and safety

Falling copper content in concentrates traded: more impurities adding to higher downstream processing costs

Potentially more international agreements on a global regulation of mineral waste after approval of Minamata Convention

Increasing community pressure and legislation requirements to operate

In 2021 , over $60 \%$ of smelting capacity will be in Asia: potential requirements to deal with impurities before smelting

Higher levels of impurities such as $\mathrm{Hg}$, $\mathrm{As}$, and $\mathrm{Bi}$, increasing smelter flue dust and other hazardous wastes

More demand for smelter products, but concentrates contain increased units of $\mathrm{As}, \mathrm{Pb}$, $\mathrm{Bi}$, and other metals that need to be removed

$\sim 50 \%$ of fabrication capacity in China in 2018; raw material imports dependency to continue

No more recycled copper waste to China. EU/US/others scrap/waste to be processed somewhere

Worldwide fabricators demand high-grade scrap, but only refined copper available at a price

Falling prices in exchanges 2011-2016, but ICSG reports deficits of refined copper every year

The current practice of blending dirty concentrates with clean concentrates will become increasing challenging as overall impurity levels rise

Energy shortage and high costs

Competition with society for water access depending on geographic location

Water for agriculture or mining?
- Resource complexity and regulatory pressures.

- Increases in impurity content in concentrates.

- Bottlenecks derived from recycling restrictions.

- Energy and water access and cost.

What type of complex materials will copper smelters potentially receive in the coming years? What impurities are going to increase in the copper concentrates? How will size distribution for liberation of copper species in the concentrator impact pyrometallurgical processing? What synergies between base metals processors will be required to optimize recoveries and minimize environmental impact? Addressing these queries will allow smelters to understand how they should adjust their operations to maximize the recovery of copper and other valuable elements, and the impact on secondary streams such as slag, acid and dust.

\section{Copper Content in Ores and Concentrates}

A global copper mine-by-mine review undertaken by ICSG found that the global average copper ore grade was as low as $0.45 \%$ copper in reported reserves and only $0.65 \%$ copper in 2015 copper mine production. Global weighted average of copper concentrate output in a large sample of plants was around $25 \%$ copper in 2015 data. There are significant data published on the falling copper ore grades in recent decades, but a factor of concern is that the ore grades in recently operational mines are not over $0.53 \%$, while copper grades in new projects and in undeveloped mines are not over $0.43 \%$ copper on average. $^{2}$

The results of the copper mine ore grades survey carried out by the ICSG are shown in Fig. 1. A review of the copper reserves in million tonnes of copper and the copper ore grades (percentage of copper) using the latest data for the top 56 copper mines of the world, ranked by reserves, produced the following findings: only 9 of the 56 copper mines with the largest reserves of copper presented copper ore grades over $1 \%$ copper content; and only 7 of the 56 copper mines with more copper reserves presented reserves over 40 million tonnes each. So, in 40 cases, representing almost $73 \%$ of the copper mines with important reported reserves, the copper ore grades are below 1\% copper and the reserves are below 40 million tonnes copper content.

If we consider only the top 20 copper mines with the most important reserves of copper (over 1,000 million tonnes of copper reserves) the average 


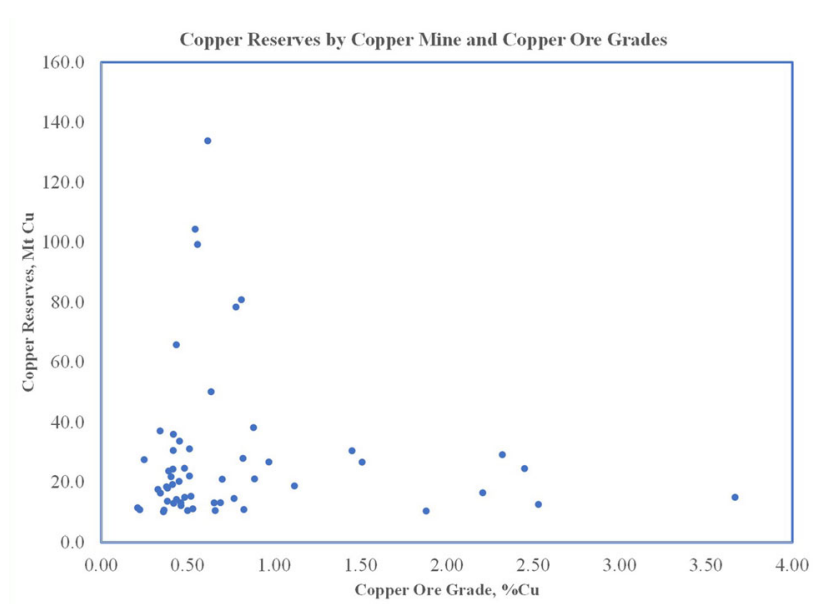

Fig. 1. Copper mine reserves versus copper ore grades; survey by ICSG. $^{2}$

copper ore grade of this group is only $0.76 \%$ copper, including deposits with a high average copper ore grade, such as Tenke Fungurume with $2.32 \% \mathrm{Cu}$, Resolution with $1.5 \% \mathrm{Cu}$, Taimyr Peninsula (Nor'ilsk-Talnakh) with $1.45 \% \mathrm{Cu}$ and Udokan with $0.97 \% \mathrm{Cu}$. Other mines with relatively high ore grades include the Ertsberg-Grasberg Group with $0.88 \% \mathrm{Cu}$, Rosario-Rosario Oeste with $0.82 \% \mathrm{Cu}$, Collahuasi with $0.81 \% \mathrm{Cu}$, and Olympic Dam with $0.78 \% \mathrm{Cu}$. Lower ore grades are reported in mines with high reserves, such as Los Bronces-Los Bronces Sur with $0.64 \% \mathrm{Cu}$ ), Andina with $0.62 \% \mathrm{Cu}$, but with the largest reported reserves, El Teniente with $0.56 \% \mathrm{Cu}$, Escondida-Main Mine with $0.54 \% \mathrm{Cu}$, the largest producer in recent decades, and Los Pelambres with $0.51 \% \mathrm{Cu}$.

If we look at mines with high reserve volumes and lower copper contents, we can report Butte Group with $0.48 \% \mathrm{Cu}$. The reserves in the expansion of Escondida-Pampa Escondida only report $0.45 \% \mathrm{Cu}$, meanwhile Chuquicamata report $0.43 \% \mathrm{Cu}$, similar to Buenavista del Cobre (Cananea) reporting $0.42 \% \mathrm{Cu}$, and Radomiro Tomic also reporting $0.42 \% \mathrm{Cu}$. Lower grades in large reserves are reported by the Pebble project with only $0.34 \% \mathrm{Cu}$ and Morenci with $0.25 \% \mathrm{Cu}$.

\section{Ore Grades and Technologies}

Many copper resources and reserves in mineral deposits report higher copper content than porphyry deposit, however, the most abundant low-grade porphyry deposits were mined first, and this is the reason why global copper ore grades went down on average during 1990-2018. Current technology to extract low-grade copper reserves indicates that higher-grade copper deposits are not necessarily mined first. Many low ore grade deposits remain operating as is the case of Morenci, Toquepala, Cerro Verde, Centinela, Quebrada Blanca, Cuajone, Radomiro Tomic, and Los Bronces. The grade produced from established mines tends to reduce with age. Other relatively low-grades deposit, such as Quellaveco, are advancing in the project pipeline. However other high-grade deposits, such as the Olympic Dam expansions, Pokowice, Oyu Tolgoy, Grasberg Underground, and other higher ore grade projects, are slowly advancing to the production stage. $^{3}$

Higher throughput rates and more efficient mineral processing has maintained copper output; however, with lower feed copper content and increasing energy and water use per unit of output, extraction costs have been increasing in important copper mines. Using the Chilean copper mining industry as an example, the use of fossil fuels increased over $33 \%$ in $2010-2018$, while the use of electricity increased by around $38 \%$ in this same period. ${ }^{4}$

From the mine processing point of view, the reduction in ore grades and mineralogy changes suggest the need to adapt current mining and mineral processing techniques to maintain production targets of metal units and quality. However, in some cases, opposite strategies have been followed. For example, some Chinese operations have processed low-grade copper concentrates. ${ }^{5}$ These trends suggest a dynamic balance between copper mines and processers in terms of defining where to invest and where is the best place to remove each impurity. This requires a balance between metal recovery, processing cost, acid production, and slag generation.

\section{Concentrate Quality}

Figure 2 shows data on the composition of 32 major traded concentrates, with the mineral composition calculated from publicly available assay data (which should therefore be considered to be approximate). ${ }^{6}$ Expanding the data to 180 traded concentrates shows an average grade of $27 \% \mathrm{Cu}$, even though concentrates average only around 55$60 \%$ copper sulfides. This is due to the presence of the minerals chalcocite $(79.9 \% \mathrm{Cu})$ and covellite $(66.4 \% \mathrm{Cu})$, which are much higher grade than chalcopyrite $(34.6 \% \mathrm{Cu})$.

However, chalcocite and covellite are secondary copper sulfides that occur in higher proportions in the close-to-surface ore zones. As the shallower zones are depleted, more mines are moving into deeper areas with increased primary mineralization, that is, a higher proportion of copper is contained in chalcopyrite (New African deposits are the exception to the industry trend towards higher chalcopyrite, but concentrates from African mines are rarely traded internationally.) This will cause a gradual decrease in the copper concentrate grade of traded concentrates, unless efforts are made to make concentrates mineralogically cleaner; that is, the proportion of copper sulfides would have 


\section{Copper Concentrate Mineralogies}

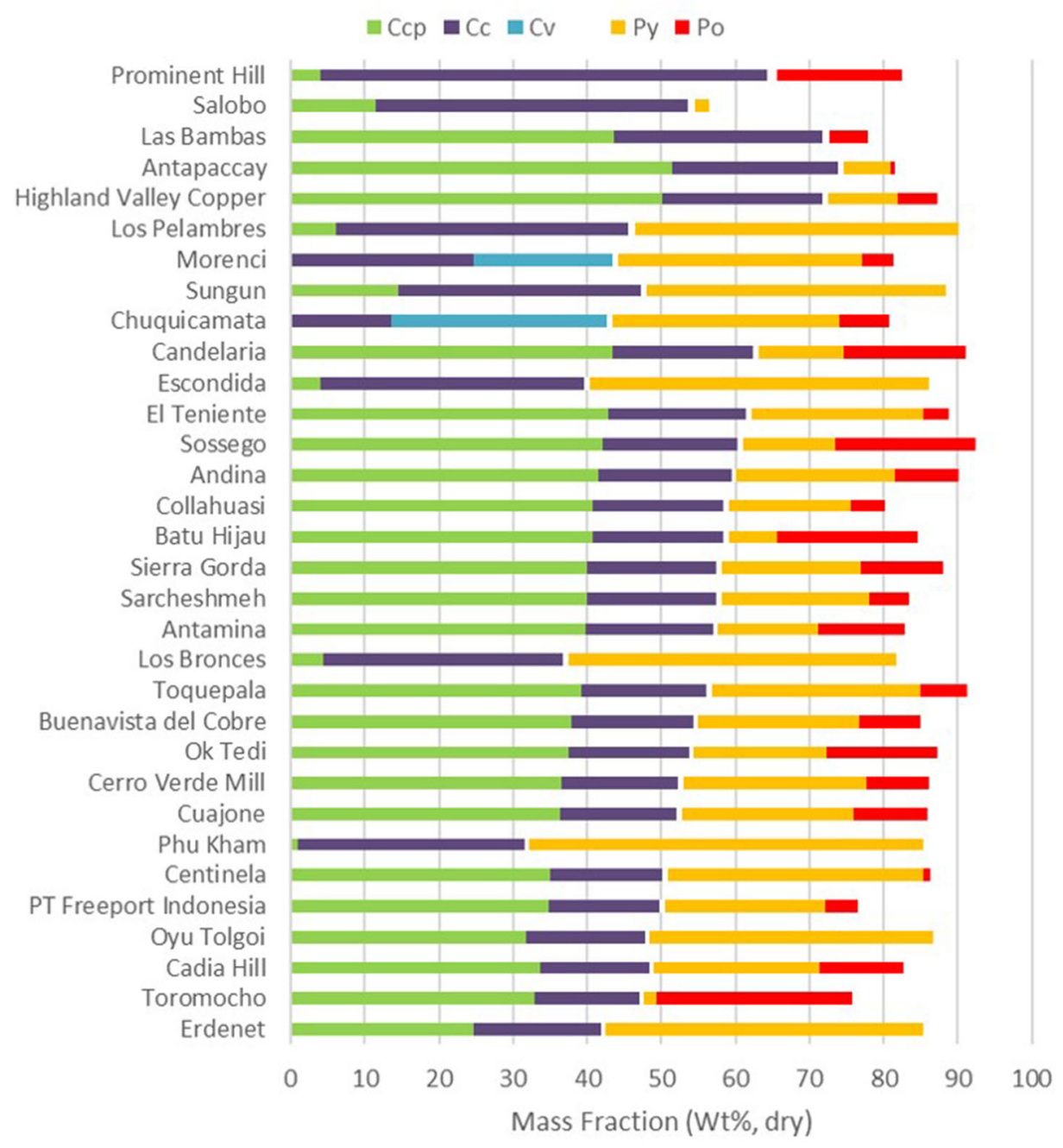

Fig. 2. Estimated mineral composition of major traded copper concentrates; $C c p$ chalcopyrite, $C c$ chalcocite, $C V$ covellite, $P y$ pyrite and $P o$ pyrrhotite.

to increase above the current level of $55-60 \%$ by removing more iron sulfides and non-sulfide gangue minerals. To achieve this, concentrators would need to increase the mineral processing "power", including finer regrinding and more intense flotation cleaning of the concentrates. These modifications to grinding and flotation require more capital investment and increase operating costs at the mine site, so many operators will choose to pass the lower-grade concentrates to smelters instead, so long as their concentrate is marketable and the penalties are less than the required capital and operating costs. This is reflected in the increase in the use of blending facilities as the primary tool to reduce the impact of complexity in smelters. Figure 3 shows the blending facilities strategically located around the globe.

\section{COMPLEXITY IN COPPER CONCENTRATES AND POTENTIAL COUNTER MEASURE IN COPPER SMELTING}

Table II summarizes the effects on copper smelting of this trend to the increasing proportion of copper from chalcopyrite from deeper copper mines.

Increases in gangue and sulfur content directly impact the production of slag and sulfuric acid, both considered secondary products in copper production. Minor element concentration will not only affect the secondary products but also the main output of the smelter, copper anodes. Figure 4 shows a comparison for copper anode impurities between 2007 and 2019: ${ }^{8}$ arsenic, tellurium, bismuth, selenium, nickel, and antimony concentrations in copper anodes have all increased. 


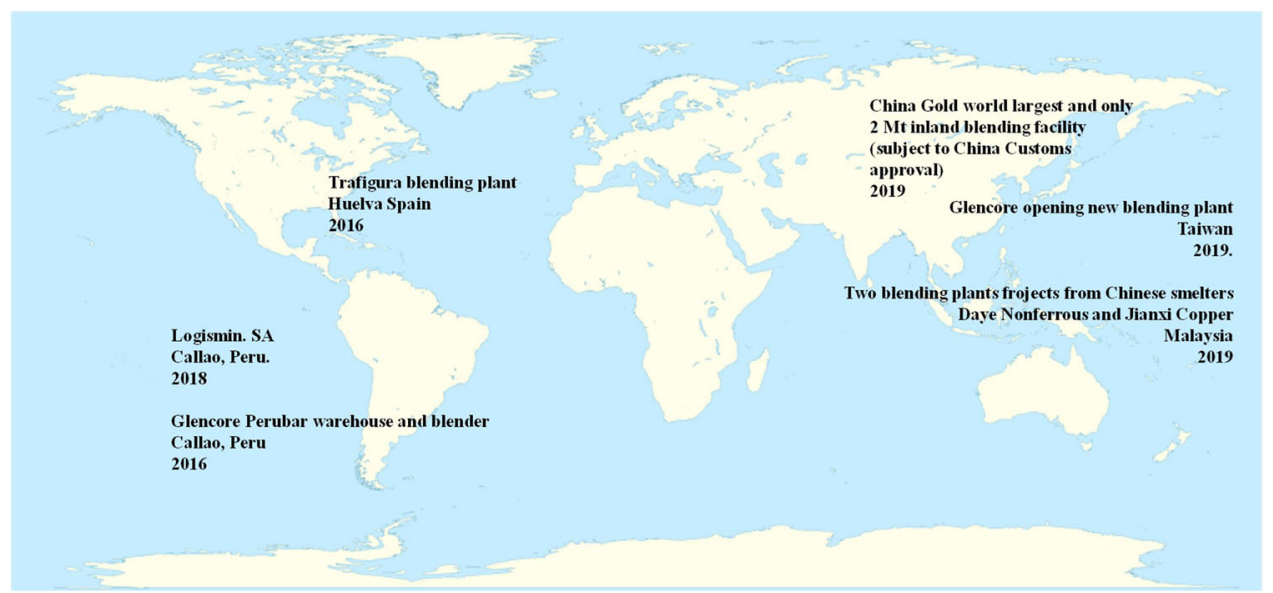

Fig. 3. Recent blending facilities ${ }^{1,7}$ (map source: https://commons.wikimedia.org/wiki/File:Worldmap_wdb_combined.svg, licensed under CC BY-SA).

Table II. Concentrate complexity and impact on copper smelting

\section{Concentrate output}

Lower copper
concentrate
(general)

Increase in pyrite

Increase in

$\mathrm{Pb}$ and $\mathrm{Zn}$

Increase in the concentration of deleterious elements

\section{Impact on copper smelting}

Potential impact on furnace heat balance due to increase sulfur content potentially balanced by gangue content in the concentrate

Increased slag generation

Increased copper losses as slag amounts increase

Increased acid production (higher sulfur content)

Alumina: An increment in alumina content in the feed will increase slag viscosity. Copper losses potentially impacted due to increased matte entrained (i.e., increase in $\mathrm{Al}_{2} \mathrm{O}_{3}$ content in slag over $4 \%$ could drastically increases slag viscosity)

Magnesia: Impact on slag liquidus temperature required to increase operating temperature to keep slag with required fluidity, depending on smelting technology

Iron oxide: Will require addition fluxing agent (silica) to keep $\mathrm{Fe} / \mathrm{SiO}_{2}$ target Increase in slag generation

Direct impact on heat balance of the furnace might result in reducing copper matte grade or additional cooling agents (reverts) to balance heat, replacing new feed, and reducing produced copper units

Increase in zinc content in slag (bath smelting) and dust (flash furnace) might allow options to recover via dust leaching

Lead

Increase in dust concentration during converting process might also option for recovery via dust leaching in an integrated $\mathrm{Cu}-\mathrm{As}-\mathrm{Pb}-\mathrm{Zn}$ recovery circuit

Potential requirement for a lead removal stage at the end of copper blowing by adding silicacontaining fluxes. Slag will need to be recycled to smelting unit

Arsenic: Increase in arsenic concentration in streams from primary smelting reactor:

Requirements for additional operating costs in gas cleaning

Increase in arsenic concentration in slag could jeopardize slag disposal or use in secondary applications

Increase in arsenic in anode could require use of fluxing to meet anode standards

Halogens: Increase in mercury, fluorine, and chlorines in concentrate:

Additional gas cleaning required

Precious metal losses to gas might increase due to volatilization as chlorides

Corrosion of gas-cleaning equipment 


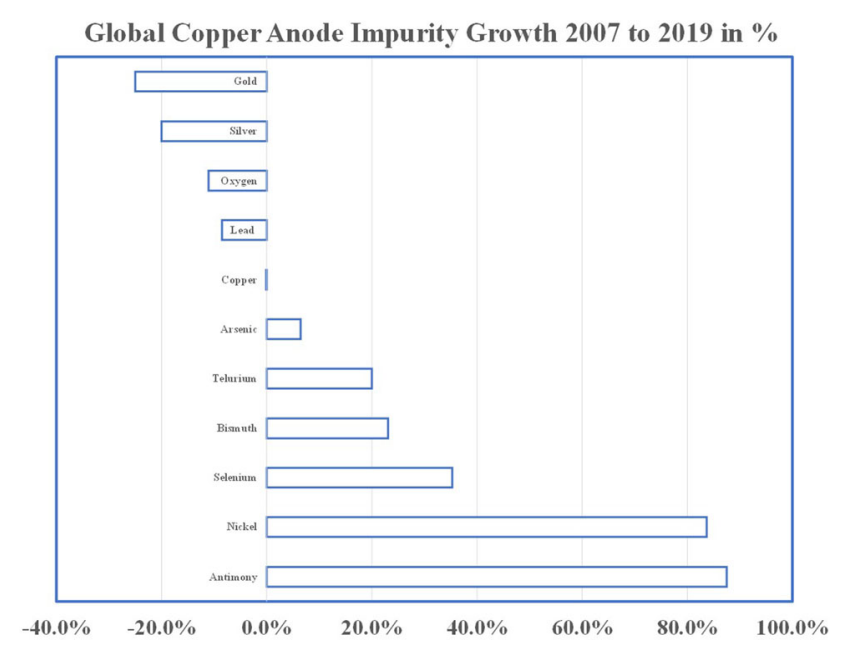

Fig. 4. Global copper anode impurity growth 2007-2019 ${ }^{8}$.

This increase in impurities in the copper anodes has not only affected the electrorefining process but also intermediate streams, sub-product quality, and the options for dust and residue recycling to the smelting furnace. This has increased the need to incorporate bleeding options or synergies with other base metal operations to achieve more sustainable metal recovery, waste stabilization, and overall sustainable processing.

\section{PROCESSING OF COPPER COMPLEX MATERIALS IN THE COPPER INDUSTRY}

Pyrometallurgical processing of complex copper concentrates has been traditionally associated with the smelting of specific materials containing substantial concentrations of deleterious elements, such as arsenic and/or smelted polymetallic base metal concentrates containing relevant quantities of copper, lead, and zinc as carrier metals, associated with precious metals and other elements. In most cases, such materials have been processed in facilities integrated with or close to the mine site. Examples include the processing of $\mathrm{Cu}$-As concentrates in Kosaka in Japan, the roasting of $\mathrm{Cu}-\mathrm{As}$ concentrates at El Indio in Chile, and the processing of $\mathrm{Cu}-\mathrm{As}$ concentrates from the Consolidated Mine in The Philippines at the Lepanto Roaster. ${ }^{9}$ Most of these plants have had a limited operating life, as they were originally designed to treat specific mine resources with a limited mine life. However, with the commissioning of the Ministro Hales roaster in Chile, a renewed interest in roasting has emerged as a niche solution for processing high-arsenic concentrates. This could potentially allow simpler and more cost-effective integrated metallurgical plants using one-step pyrometallurgical processing, i.e., direct-to-blister processing of roaster calcine. In principle, the overall capital cost of such a facility should be competitive considering the reduction in equipment and material handling.
In the case of polymetallic concentrates, a more robust approach to increase metal recovery and multi-metal production has been to develop multimetal recovery facilities. The main goals of these facilities are to achieve maximum metal recoveries and optimum waste and effluent management by the exchange of metal flows between the different metallurgical circuits. This principle, shown in Fig. 5, is applied in metallurgical integrated plants, such as the Kazzinc Ust-Kamenogorsk Metallurgical Complex in Kazakhstan, ${ }^{10}$ the Boliden Rönnskär Smelter, ${ }^{11}$ or in multi-integrated sites in Japan, ${ }^{12}$ Germany ${ }^{13}$ and Korea, ${ }^{14}$ among others.

However, even in these integrated facilities, it still not yet feasible to recover elements such as W, $\mathrm{Mo}, \mathrm{V}, \mathrm{Mn}, \mathrm{Cr}, \mathrm{Nb}, \mathrm{Ta}, \mathrm{Li}$, and the rare earths. Considering the future challenges that will arise from processing increasing quantities of batteries, additional efforts will be required to adapt metallurgical circuits to recover new elements.

Additional efforts have been made in countries like Japan and Germany to develop technologies to recover rare metals from waste from small electronic and electric appliances, prioritizing pre-processing of these materials before being fed into copper smelting circuits. ${ }^{16}$ The aim is to improve recovery rates and the range of elements that can be economically recovered.

Table III shows a compilation of metallurgical complex processing plants that were or are currently operating in the western world, aiming to use base metal carrier properties to optimize and maximize precious metal recovery. In most of these plants, base metal volume production is not as relevant as the concentration of valuable precious metals. These plants can potentially process industrial wastes, city incinerator metallic sub-products, recycling oils, and others. Countries like Korea and Japan have been pioneers in this approach at their non-ferrous operating plants.

\section{Example 1: Japanese Approach Primary and Secondary Materials Integrated Complexity; JX Nippon Mining Flowsheet ${ }^{12}$}

Metallurgical plants in Japan are using a similar approach by integrating primary and secondary complex processing sites and maximizing synergies between them to increase metal recovery. In the case of Japan, special emphasis has been made to process complex secondary raw materials and industrial waste using the ability of existing smelting facilities to recover valuable metals. Figure 6 shows the concept applied by JX Nippon Mining to combine primary resources with secondary and industrial waste resources.

\section{Example 2: Aurubis Primary and Secondary Materials Processing Systems}

Figure 7 shows the process flowsheet of the lead secondary copper smelter. ${ }^{20}$ The flowsheet allows 


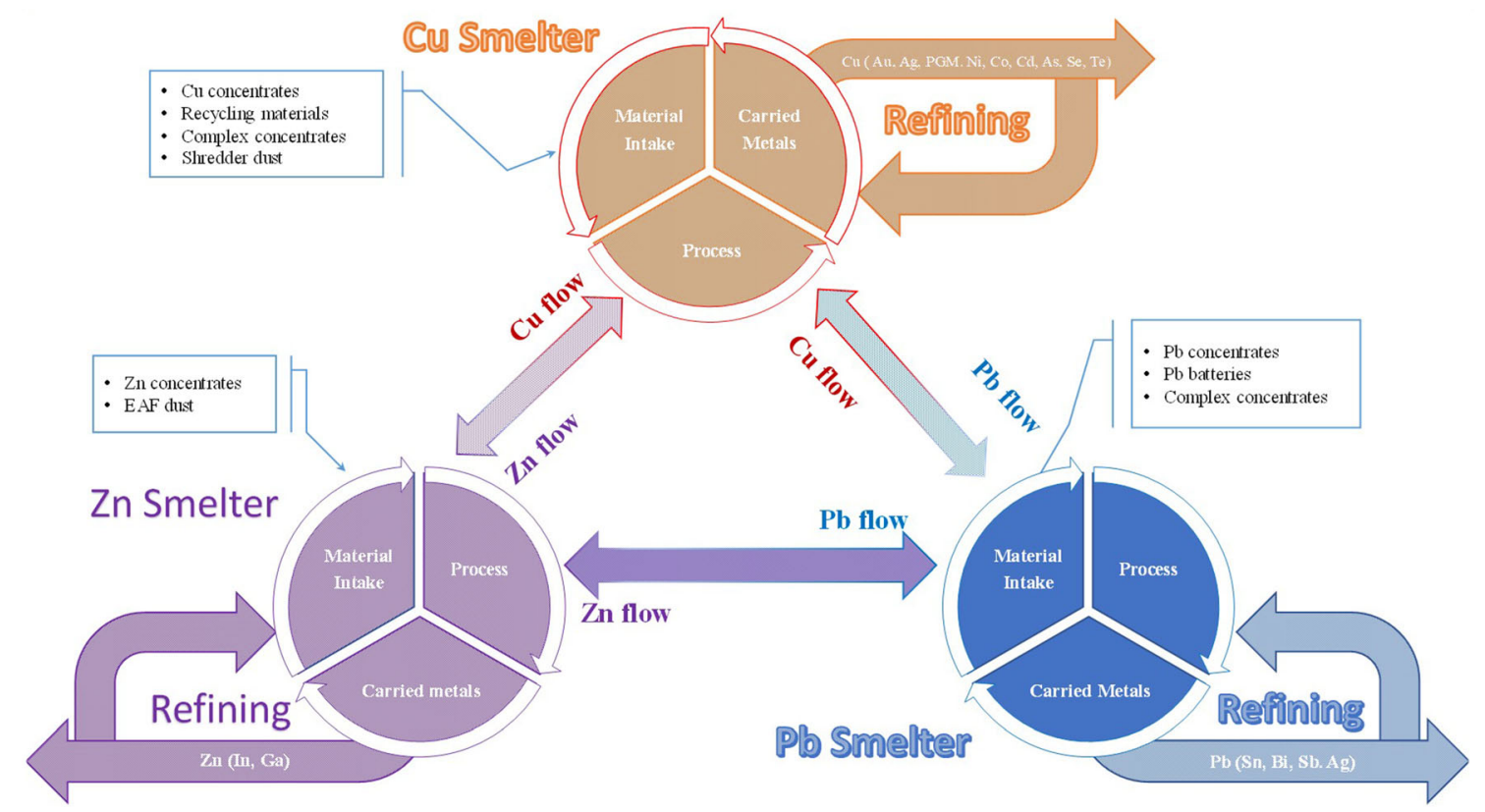

Fig. 5. Multi-metal recovery flows in a Cu-Pb-Zn integrated copper plant (modified from Nakamura ${ }^{15}$ ).

the integration and transfer of materials with the primary copper smelter. The lead smelter and refinery involve:

- Smelting of complex copper lead concentrates in an electric furnace.

- Converting of copper lead matte in a PeirceSmith converter.

- Refining of lead bullion.

- Integration with anode slime plant.

- Integration with precious metal refinery.

On the secondary copper side, one of the most successful expressions of an integrated recycling system has been the implementation of the Kayser Recycling System $\left(\mathrm{KRS}^{+}\right)$. This flowsheet, which was developed to recover copper, lead, tin, and precious metals, has been in operation since 2002 in Lünen, Germany. Figure 8 shows the Lünen process flowsheet. $^{23}$

The flowsheet encompasses the following unit operations:

- ISAMELT $^{\mathrm{TM}}$ furnace for smelting reduction.

- Settling furnace for copper recovery.

- $\mathrm{Pb}-\mathrm{Sn}$ furnace for $\mathrm{Pb}-\mathrm{Sn}$ alloy production.

- TBRC for copper conversion.

- Anode furnace.

\section{Example 3: Ust-Kamenogorsk Metallurgical Complex ${ }^{10,24,25}$}

The Ust-Kamenogorsk Metallurgical Complex is a multi-metal recovery plant combining lead, copper and zinc base metal metallurgy. The plant consists of:
- Zinc refinery with a capacity of 190,000 tpa.

- Lead smelter and refinery with a lead bullion production capacity of 144,000 tpa.

- Copper smelter and refinery with a copper cathode production capacity of 70,000 tpa.

A precious metal plant is also integrated into the base metal operation to produce gold and silver. The Ust-Kamenogorsk metallurgical complex is able to process highly complex materials with high recoveries given by the integrated nature of the plant. Figure 9 shows a simplified process flowsheet.

\section{THE ARSENIC CHALLENGE}

Arsenic has been a recurrent challenge in the management of deleterious elements in the processing of copper concentrates. Arsenic content has gradually increased in copper concentrates to levels that are almost above the standard arsenic blending concentrations that most western smelters in Europe, Asia (excluding China), and North America can operate. A clear example of the gradual increase of arsenic in copper concentrates can be demonstrated by the behavior in the blends processed in Japan. According to the Metals Economics Institute of Japan, arsenic content in copper concentrates processed in Japanese smelters has gradually increased since 1991 from $400 \mathrm{ppm}$ to over $1,000 \mathrm{ppm}$ in 2016 , while the copper content in the concentrates decreased from near $33 \%$ to $27 \% \mathrm{Cu}^{26}$ This represents a 3 times increase in the units of As per unit of $\mathrm{Cu}$ in the feed. The same report estimates that standard copper concentrate blends could increase to 3,000 ppm if new high As-containing deposits are brought into operation. Introducing 


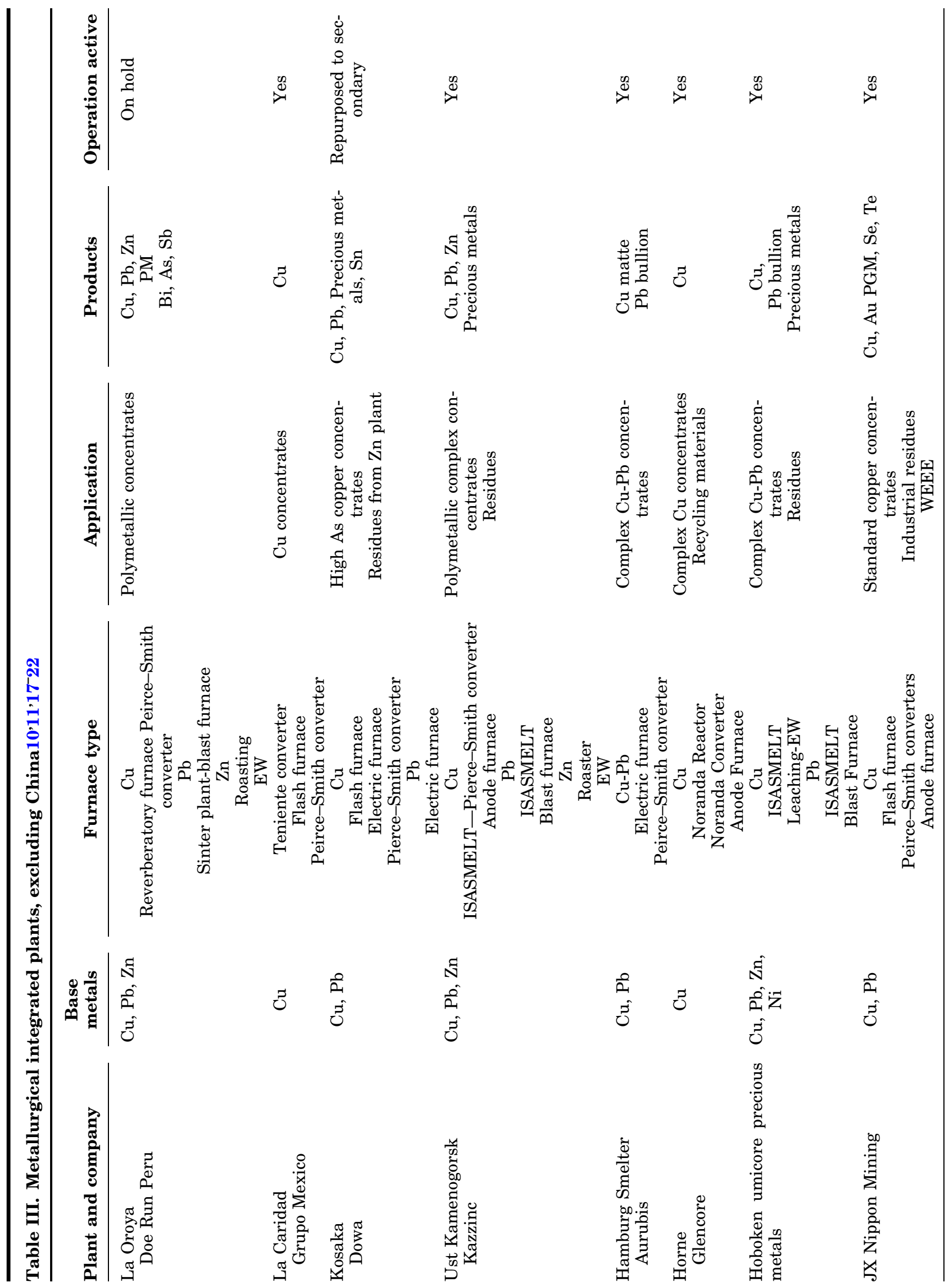




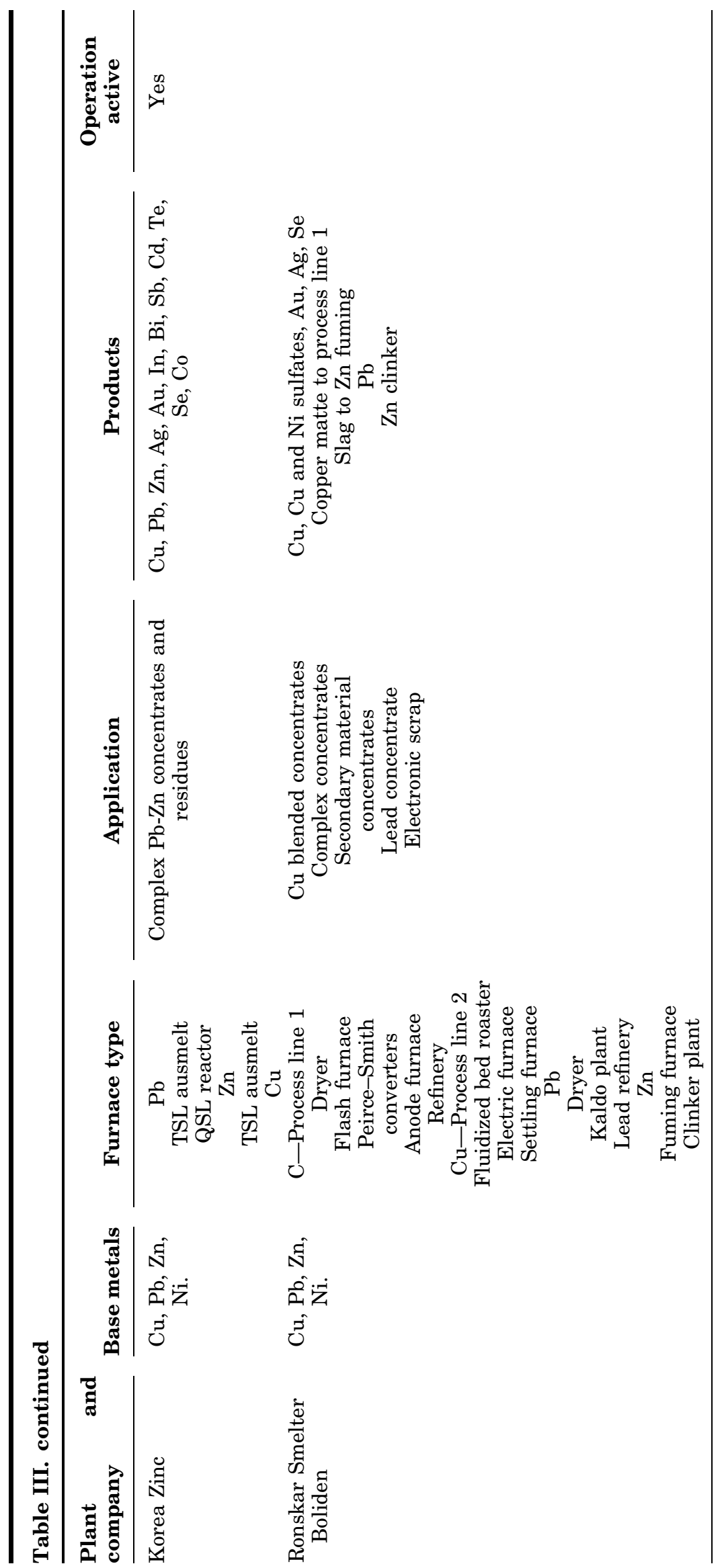




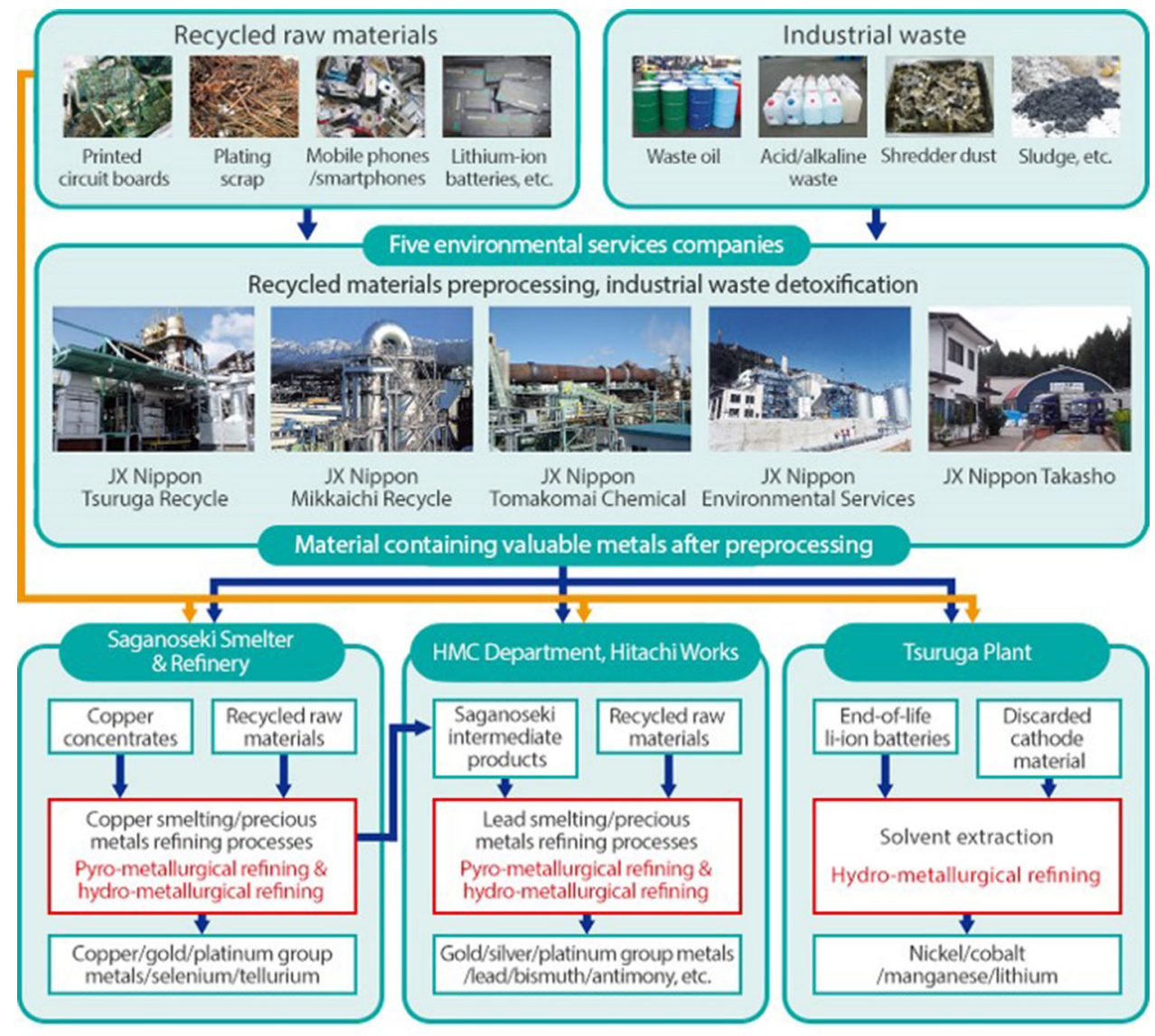

Fig. 6. JX Nippon Mining Flowsheet (reprinted with permission of JX Nippon Mining). ${ }^{12}$

such complex high-arsenic copper concentrates would require large amounts of clean concentrates to dilute the arsenic contents to levels acceptable from the technical and economic points of view by copper smelter. ${ }^{27}$

The impact of a small increase in the tonnes of high-arsenic concentrates is illustrated in Fig. $10 .^{28}$ Because of the more than tenfold higher arsenic units per unit of concentrate, what appears to be a small increase in the amount of high-arsenic concentrates forecast in Mayhew et al. ${ }^{28}$ almost doubles the arsenic units at smelting. Even if there were sufficient low-arsenic concentrates to dilute the average arsenic to acceptable limits, the smelting industry would still face a significant increase in the units (tonnes) of arsenic to be processed and disposed. This would appear to be an unsustainable position for the predominantly urban-located smelting industry. It indicates that technologies need to be adopted to reduce the arsenic content of copper concentrates at mine sites.

\section{Strategies to Process Complex Arsenic Containing Materials}

A large amount of fundamental work has been conducted to understand the behavior of arsenic in copper smelting. Thermodynamic and kinetic aspects as well as strategies to optimize capture and stabilization were summarised by Piret et al., who conducted an extensive review on the state of the art in $1989 .^{29}$ The main conclusions of the Piret review are:

- Metallurgical slags offer a limited capacity to capture arsenic, mainly due to the reducing conditions in which they are treated.

- Gas phase elimination and subsequent processing of condensed dust are more suitable for arsenic capture.

- Arsenic capture as speiss form is advantageous.

- Recycling of intermediate products should be directed to processes in which arsenic can be effectively separated from the metal phase.

- Hydrometallurgical processing is the most suitable process route for separate processing of intermediate arsenic-containing materials.

- Effluent processing techniques allow the separation and recovery of arsenic in intermediate product. However, safe disposal of these arsenic intermediate streams will require developing environmentally stable compounds.

- Wet gas cleaning is an unavoidable step if lower gas emission standards are applied. 


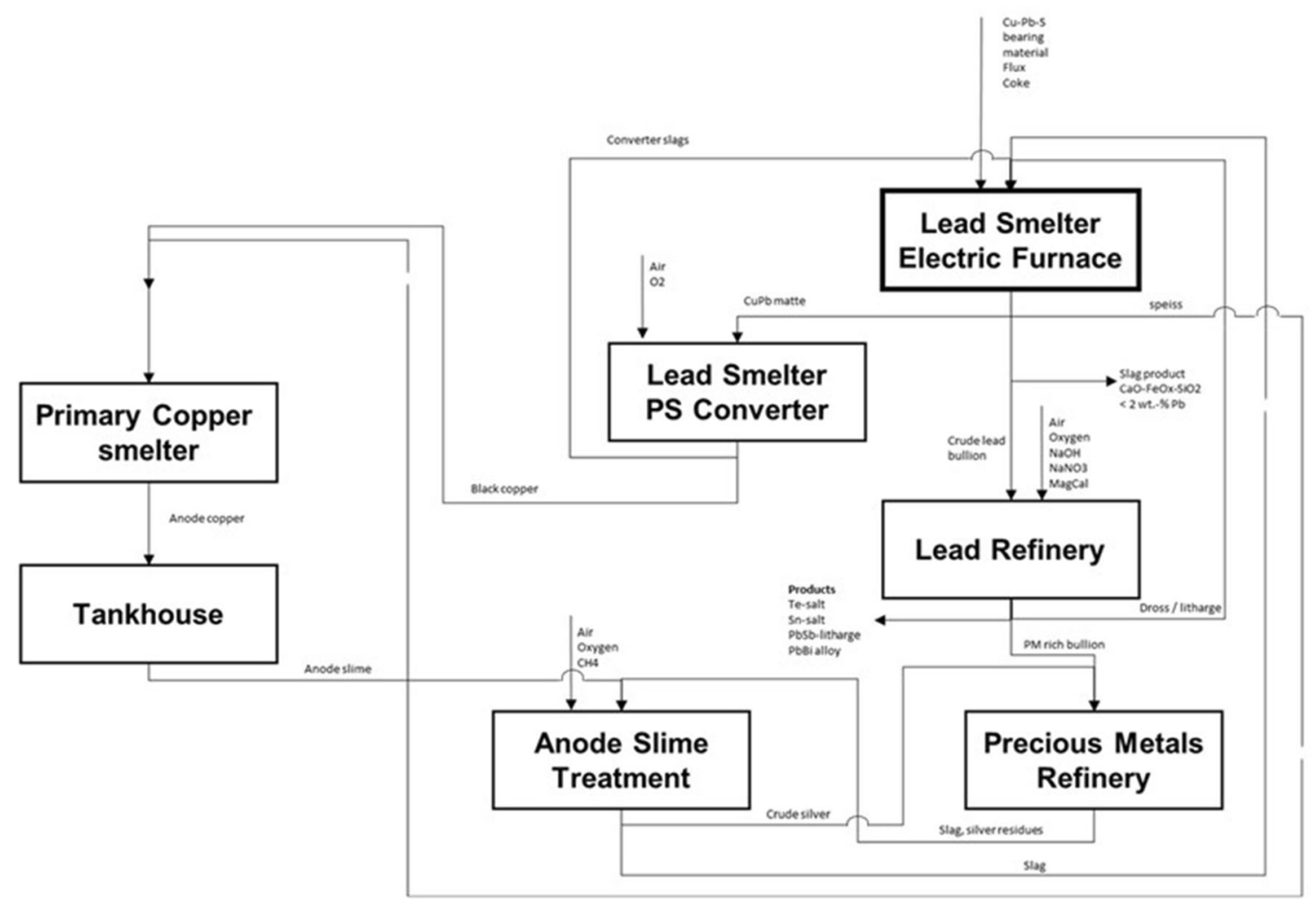

Fig. 7. Aurubis lead smelter flowsheet for processing of $\mathrm{Cu}-\mathrm{Pb}$ complex concentrates (reprinted from Extraction 2018). ${ }^{20}$

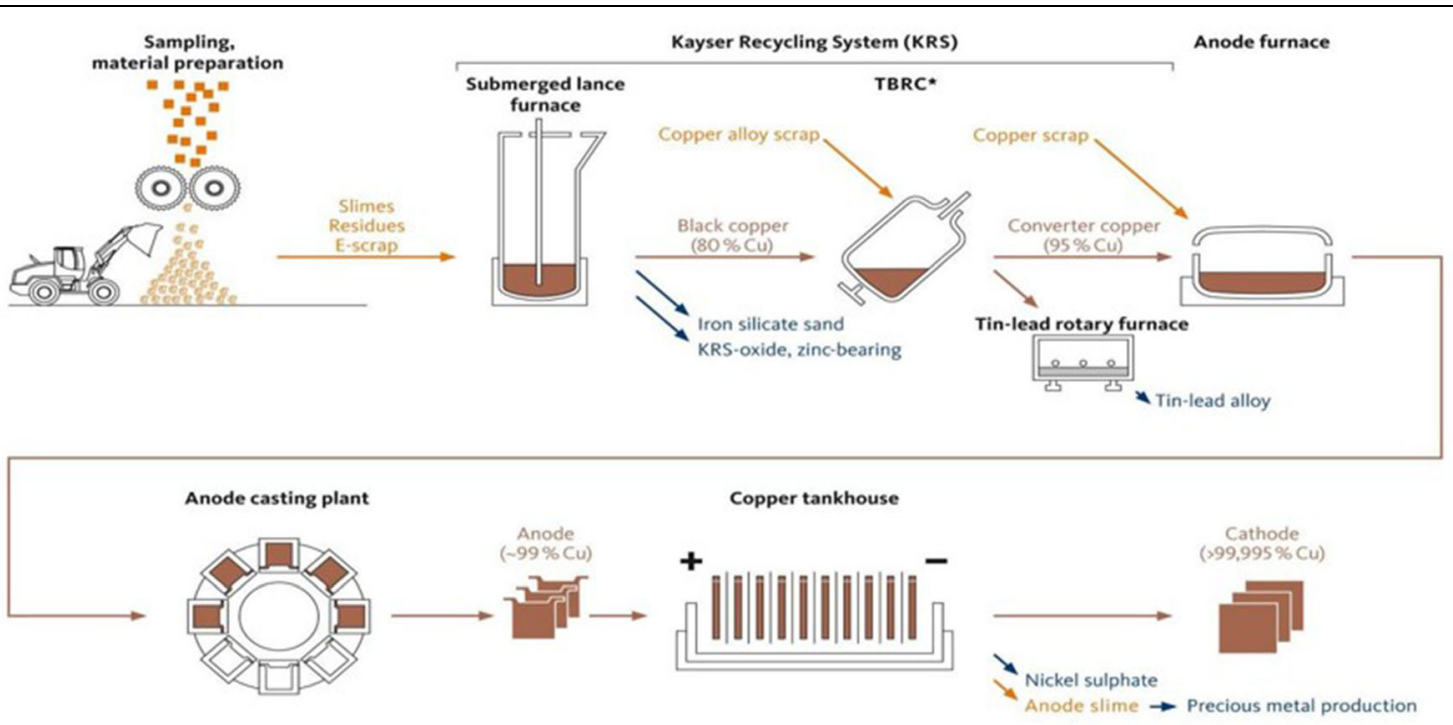

Fig. 8. Kayser recycling system $\left(K R S^{+}\right)$(reprinted from Rewas 2013). ${ }^{23}$

Most of the above criteria have been gradually applied to modern smelting operations, with new technologies being used for arsenic recovery, and safe disposal from copper smelting dust, refinery effluents, gas cleaning, and wastewater processing being gradually achieved.
In the last 30 years, a great deal of effort has also been made to develop alternative technologies to process high-arsenic-containing materials. Focus has been on:

- Developing niche technologies for processing specific ore bodies from mine to cathode using a 


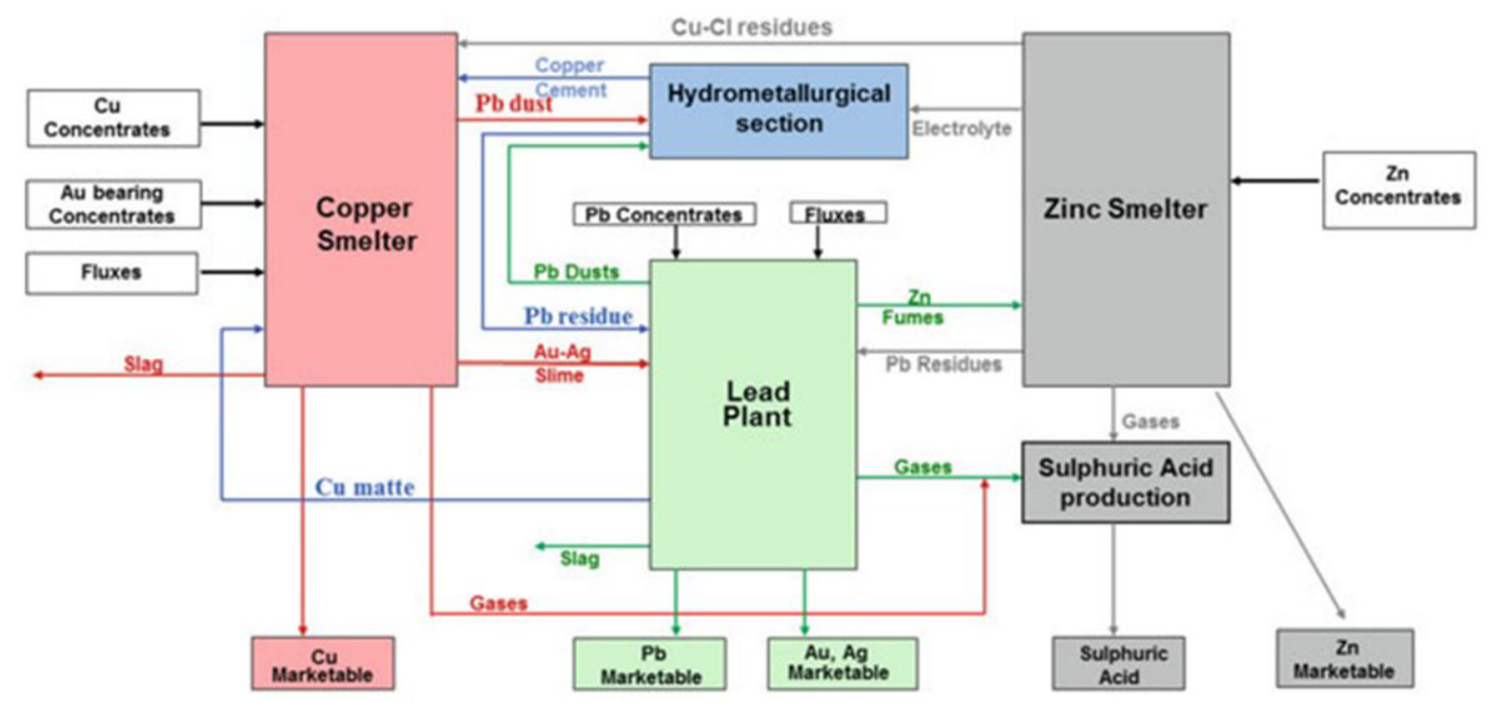

Fig. 9. Kazzinc Ust-Kamenogorsk Metallurgical Complex flowsheet (reprinted from extraction 2018). ${ }^{24}$

Contribution to kt As in Concentrate in 2024
160

120

80

40

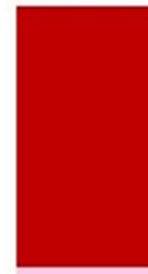

$>1 \%$ As

0.3 to $1 \% \mathrm{As}$

0.15 to $0.3 \%$ As

0.1 to $0.15 \%$ As

$<0.1 \%$ As
Fig. 10. Actual and predicted arsenic levels of concentrates (calculated by the authors from a graph of actual and forecast concentrate arsenic levels reported by Mayhew et al. ${ }^{28}$ ).

combination of hydrometallurgical techniques and solvent extraction and electrowinning.

- Selective flotation to depress and concentrate high-arsenic streams.

- Renewed interest in roasting of high-arseniccontaining materials.

- Leaching of high-arsenic copper concentrates (alkaline and acid environments).

- Stabilization of arsenic residues in crystalline stable structures such as scorodite.

- Vitrification of high-arsenic-containing materials in smelting slags.
Table IV shows the level of development of some technology responses for processing complex arsenic-containing materials. ${ }^{30},{ }^{31}$ Most of these technologies have been developed to process higharsenic-containing streams. However, with blending continuing to be the most popular approach, a gradual increase in arsenic content in copper concentrates-and a faster increase in the tonnes of arsenic processed-should be expected. This will exert more pressure on smelters, increasing their operating costs, jeopardizing their competitiveness, and increasing environmental compliance requirements.

Complexity, therefore, can be understood not only in terms of supply but also in terms of the effect on the business need to invest in peripherical equipment to increase capture, reduce emissions, and stabilize residues according to local regulations.

This gradual increase associated with operational procedures aimed to minimize waste outlets has gradually increased arsenic concentration in slags and, subsequently, reduced market opportunities for sub-products. Several efforts are currently undergoing in Chile, Germany, Australia, Japan, and Canada, among others, to develop pre-processing alternatives for safe arsenic removal prior to smelting or processing of secondary streams generated in the copper smelting processes.

The last two items in Table IV should be the first investigated in any integrated industry response. It is almost always more efficient to remove an impurity at ambient temperature and pressure in mineral processing rather than in smelting-so long as that impurity is in a discrete identifiable mineral. When arsenic in the current "baseload" of traded concentrates occurs in the form of arsenopyrite (FeAsS), or is apparently dissolved in iron sulfides, 
Table IV. Some technology responses for the processing of complex arsenic-containing materials

\begin{tabular}{llc}
\hline Category & \multicolumn{1}{c}{ Technology and main feature claims } & Status of development \\
\cline { 3 - 3 } Atmospheric leaching & FLSmidth Ferric Leaching (ROL process) & Pilot scale \\
& $\begin{array}{l}\text { Albion process } \\
\text { Galvanox }\end{array}$ & Industrial scale \\
& Toowong process & Pilot scale \\
& Polysulfide & Pilot scale \\
& INTEC & Discontinued for copper \\
& Hydrocopper & Demonstration scale \\
& Nikko chlorination & Demonstration scale \\
& BioCop & Demonstration scale \\
& Equity silver & Demonstration scale \\
& Sumitomo chlorination & Industrial scale \\
Pressure leaching & Seppon copper process & Industrial scale \\
& POX & Industrial scale \\
& CESL & Industrial scale \\
Roasting & Demonstration plant & Demonstration plant \\
& PLATSOL & Discontinued \\
Vitrification & Boliden & Pilot scale \\
Mineral processing & Concentrate processing & Industrial scale \\
Selective flotation & Dundee Sustainable Technologies & Separation of arsenic-bearing from non-arsenic-bearing minerals \\
\hline
\end{tabular}

then it can be reduced by mineral separation applying modern fine regrinding and washed-froth cleaning. This is more technically efficient than removing the arsenic in smelting, but it is not always more economic for the miner. Though the technology is well proven, it requires capital investment and increases mine-site operating costs. Current concentrate contracts do not generally reward this investment-that is, they do not send the correct cost "signals" to achieve the most efficient solution for the overall processing industry. Usually mine sites only adopt these technologies if they are essential to market their concentrate-for example, some of the sites that produce the highest quality concentrates in Fig. 2 do so in order to achieve limits on impurities such as $\mathrm{U}$ or $\mathrm{F}$. The mineral processing steps to reduce the impurities to acceptable levels for marketing coincidentally reduce other mineral contamination, resulting in a significantly higher concentrate grade in high copper recovery (though in a finer-grained concentrate). If more accurate economic signals were sent through concentrate contracts, or if the copper industry agreed to an "arsenic code", then the average arsenic level of currently traded concentrates could also be reduced.

A much more difficult mineral processing challenge is the selective flotation of arsenic-bearing copper minerals (e.g., enargite, $\mathrm{Cu}_{3} \mathrm{AsS}_{4}$, and tennantite, $\left.(\mathrm{Cu}, \mathrm{Fe})_{12} \mathrm{As}_{4} \mathrm{~S}_{13}\right)$. These minerals have flotation characteristics very similar to nonarsenic-bearing copper minerals (chalcopyrite, chalcocite and bornite). Very small chemical "windows" for partial separation have been demonstrated in laboratory work, but these do not appear robust enough for practical application. Even if they were, they would still only split the same amount of arsenic between a low-arsenic copper concentrate and a high-arsenic copper concentrate. Either way, a new processing technology needs to be adopted if the copper industry is to avoid the transport and smelting of increased units of arsenic from these deposits. The atmospheric leaching processes in Table IV appear the most likely candidates, and they could be applied on-site or at a central facility to reduce arsenic content and dispose it locally and safely before transport to smelters.

\section{RECOGNIZING COMPLEXITY AS A DRIVER FOR THE FUTURE}

Primary and secondary sources of base metals are gradually increasing in complexity. This complexity includes lower grade ore, lower grade concentrates, and increases in the concentration of minor metals and slagging elements. This pattern has clearly affected non-ferrous metal production, increasing operating costs, environmental compliance pressures, and the investment required to ensure a sustainable production of metals.

Alvear et al. ${ }^{32}$ discussed some key elements associated with the increasing complexity for primary copper production. This has been observed in the operation of secondary materials, such as the Kayser Recycling System, with increasing complexity and reduction in the concentration of base and precious metals in the sourced raw materials.

This pattern constantly challenges the competitiveness of smelters, who need regular evaluation of cost-effective measures to remain competitive. This 
is the most critical question for producers: How to differentiate from each other in an industry that has been traditionally regarded as a commodity business with common technologies.

Clearly, adequate technology transformation, selection and performance will play a crucial role in this race to enhance (1) superior metallurgical performance, (2) a sustainable and environmentally friendly operation, (3) adequate impurity management, and (4) proper product quality.

Asset optimization is key. In a previous publication, we recognized the following elements as essential aspects to adjust metallurgical operations to the change in supply:

- Flexibility of the process configuration to adapt to new grades: find new operating conditions and adjust production to this reality.

- Interaction with concentrate suppliers and ability to blend and stabilize smelting assets on a regular basis if possible.

- Ability to maximize impurity processing capacity.

- Energy utilization: how to adjust operating conditions for a given feed to optimize energy efficiency and utilization.

- Ultimately, considerations for new/improved technologies to meet the challenge of resource efficiency.

To this list, we add the need for better integration of mine-site technologies with smelting, to find the most efficient place for the industry to remove impurities. This requires constructive dialogue between miners and smelters. When the most efficient technical option is identified, then either concentrate contracts should send the right market signals, or the industry may need to agree to a code of practice to achieve the most sustainable outcome.

\section{KNOWLEDGE INTEGRATION: FROM FUNDAMENTAL KNOWLEDGE TO TECHNOLOGY IMPLEMENTATION}

Knowledge integration plays a key role in the conceptualization and development of metallurgical processes. As complexity is expected to rise, modifications of existing metallurgical processes and/or developments of new ones will be required. Increased amounts of minor elements from copper complex concentrates as well as complex e-wastes and industrial residues will require sustainable processing.

In addition, with e-mobility as a target for the future, new processes able to recycle and recover battery elements will be required. These potential new processes will benefit from synergies from existing metallurgical plants; however, careful evaluation of the impact on existing streams will be required. New smelters will need to move from a standard processing that is becoming more competitive and less profitable to explore processing of complex urban wastes, metallurgical residues, and complex materials to secure profitable business. Competition with low-cost smelters, mostly located in China, will become more difficult.

As these operations move to consider new business opportunities, integrated approaches to develop technologies will be required. Integration will mean not only technical knowledge but also business expertise in non-traditional materials and full understanding of supply chains.

Table V. Basic elements required to foster an integrated technology development approach

\begin{tabular}{|c|c|}
\hline Basic elements & Main features \\
\hline \multirow{3}{*}{$\begin{array}{l}\text { Market } \\
\text { understanding }\end{array}$} & Understanding main drivers behind metals markets \\
\hline & Who are the main actors and where are they playing? \\
\hline & Awareness of commercial, technical, and environmental limitations \\
\hline \multirow{2}{*}{$\begin{array}{l}\text { Technology road } \\
\text { mapping }\end{array}$} & Clear understanding of limitations and capabilities of technologies and processes \\
\hline & Ability to assess technological status of competitors \\
\hline \multirow{3}{*}{$\begin{array}{l}\text { Comprehensive } \\
\text { process } \\
\text { knowledge }\end{array}$} & Capacity to understand current processes and fundamentals behind them \\
\hline & Holistic analytical capabilities \\
\hline & Integrated multidisciplinary thinking \\
\hline \multirow{2}{*}{$\begin{array}{l}\text { Technological } \\
\text { support }\end{array}$} & Appropriate laboratory and/or pilot plant access \\
\hline & Process modeling capabilities to properly represent metallurgical processes \\
\hline $\begin{array}{l}\text { Intelligent and } \\
\text { effective } \\
\text { networking }\end{array}$ & To know where to go and what to ask when needed to accelerate learning process \\
\hline $\begin{array}{l}\text { Engineering } \\
\text { design } \\
\text { capabilities }\end{array}$ & $\begin{array}{l}\text { Clear awareness of engineering scale-up process to enable proper development, engineering, } \\
\text { and transfer of technological innovations }\end{array}$ \\
\hline
\end{tabular}


Key aspects to consider when analysing the need for further development of existing assets and/or new technology to meet the needs from the market are shown in Table V.

\section{CONCLUDING REMARKS}

Sustainable production of metals is of paramount importance to meet community demand along with a sustainable future of our planet. As demand for copper and contained valuable metals increases and the grade of available ores decreases, processing of more complex materials will be necessary.

The most efficient technical solutions will involve a combination of mineral processing and hydrometallurgical and pyrometallurgical processing techniques, and will include processing complex materials from both primary and secondary sources at both mine sites and smelters.

In this framework, a resource-to-cathode vision that incorporates synergies between mines, concentrators, smelters, and refineries will be required. This needs to start with open technical dialogue, followed by commercial understanding of the most efficient ways to remove impurities, and then be supported by the right market signals to achieve the more efficient outcomes.

\section{REFERENCES}

1. C. Risopatron, Impurities in Copper Raw Materials and Regulatory Advances in 2018 (Japan Oil, Gas Metals National Corporation, Tokyo, 2018). http://www.jogmec.go.jp/c ontent/300358430.pdf. Accessed 10 April 2020.

2. International Copper Study Group, Solid Wastes in Base Metal Mining, Smelting and Refining: A Comprehensive Study for the Copper, Lead, Zinc and Nickel Industries. $\mathrm{h}$ ttp://www.ilzsg.org/generic/pages/list.aspx?table=documen t\&ff aa document type=B\&from=1. Accessed 10 April 2020

3. G.M. Mudd and S.M. Jowitt, Society of Economic Geologists, Inc. Economic Geology. https://doi.org/10.5382/econgeo.2018. 4590.

4. C. Montes and A. González, Consumos de Energía y Recursos Hídricos en la Minería del Cobre al 2017 (Comisión Chilena del Cobre, Santiago, 2017). https://www.cochilco.cl/ Presentaciones/Presentaci\%C3\%B3n\%20informe\%20ener g\%C3\%ADa\%20y\%20agua\%20(2018).pdf, Accessed 15 April 2020.

5. L. Bing, Proceedings of Copper 2016. MMIJ (November 1316, Kobe, Japan, 2016), Paper PY21-3.

6. Pease, J.D. Mineralis Consultants Pty Ltd, Calculated From Industry and Public Data.

7. https://commons.wikimedia.org/wiki/File:Worldmap_wdb_co mbined.svg.

8. M.S. Moats, A. Filzwieser S. Wang, W.G. Davenport, A. Siegmund, and T. Robinson. Copper 2019. (August 18-21, Vancouver, Canada, 2019). Paper 594940, ISBN: 978-1926872-4.

9. N. Piret and A. Mellin, in International Symposium on Productivity and Technology in the Metallurgical Industry. ed. by M. Koch and J. Taylor. The Minerals, Metals \& Materials Society (September 17-22, Cologne, Germany, 1989), pp. 735-814.

10. Home page of Kazzinc. http://www.kazzinc.com/en/Ust-Ka menogorsk_Metallurgical_Complex. Accessed 15 April 2020.
11. F. Testaye, D. Lindberg, and J. Hamuyuni, Energy Technol. (2017). https://doi.org/10.1007/978-3-319-52192-3_11.

12. Home page of JX Nippon Mining \& Metals. https://www. nmm.jx-group.co.jp/english/industry/recycling/. Accessed 15 April 2020.

13. Home page of Aurubis. https://www.aurubis.com/en. Accessed 12 April 2020.

14. Home page of Korea Zinc. https://www.koreazinc.co.kr/eng lish/main/page/main.aspx. Accessed 12 April 2020.

15. T. Nakamura, Copper 2013 (December 1-4, Santiago, Chile, 2013).

16. Home page of the Japan Oil, Gas Metals National Corporation. http://www.jogmec.go.jp/english/stockpiling/metal_1 0_000002.html. Accessed 12 April 2020.

17. E. Partelpoeg, Review of La Oroya Smelter (2014). http://ic sidfiles.worldbank.org/icsid/ICSIDBLOBS/OnlineAwards/C 3004/Partelpoeg\%20-\%20Expert\%20Report\%20-\%20201402 18\%20-Final_Eng.pdf. Accessed 12 April 2020.

18. T.G. Goonan, Flows of Selected Materials Associated with World Copper Smelting (USGS, 2014). https://pubs.usgs.gov/ of/2004/1395/2004-1395.pdf. Accessed 12 April 2020.

19. Home page of Dowa Eco-System. https://www.dowa-eco.co. jp/en/group/KSR. Accessed 12 April 2020.

20. C. Zschiesche, M. Ayhan, and J. Antrekowitsch, Extraction (2018). https://doi.org/10.1007/978-3-319-95022-8_26.

21. Home page of Glencore Fonderie Horne. https://www.fonde riehorne.ca/fr/Pages/home.aspx. Accessed 12 April 2020.

22. Home page of Umicore Precious Metals Refining. https://p mr.umicore.com/en/about-us/process/. Accessed 12 April 2020.

23. G.R.F. Alvear Flores and S. Nikolic, REWAS (2013). http s://doi.org/10.1007/978-3-319-48763-2_11.

24. A. Burrows and T. Azekenov, Extraction (2018). https://doi. org/10.1007/978-3-319-95022-8_29.

25. A.S. Burrows, G.R.F. Alvear Flores, and A.T. Tynybayev, in Proceedings of $\mathrm{Cu}$ 2013, Vol III Pyrometallurgy. Eds. by. R. Bassa, R. Parra, A. Luraschi, and S. Demetrio. IIMCH (December 1-4, Santiago, Chile, 2013), pp 39-48.

26. N. Yamazaki, Trends of Arsenic in Copper Raw Materials and its Technical Countermeasure in the Copper Industry (Japan Oil, Gas Metals National Corporation, Tokyo, 2018). http://www.jogmec.go.jp/content/300358435.pdf. Accessed 10 April 2020.

27. G.R.F. Alvear Flores, Arsenic Management for the Copper Smelting Industry (Japan Oil, Gas Metals National Corporation, Tokyo, 2018). http://www.jogmec.go.jp/content/3003 58438.pdf. Accessed 10 April 2020.

28. K. Mayhew, R. Mean, A. Lossin, and P. Barrios, in $1^{O} I n-$ ternational Seminar, Innovation in Hydrometallurgical Plants, 13th International Congress, Expomin (2014).

29. N. Piret and A. Mellin, In International Symposium on Productivity and Technology in the Metallurgical Industry, Cologne, Germany, September 17-22, 1989, Ed. by M. Koch and J. Taylor. TMS, pp. 735-814.

30. D. Dreisinger, Arsenic: The Argument for Hydrometallurgical Processing and Stabilization at the Mine Site (Japan Oil, Gas Metals National Corporation, Tokyo, 2018). http:// www.jogmec.go.jp/content/300358446.pdf. Accessed 10 April 2020.

31. Home page of Dundee Sustainable Technologies. http://dun deetechnologies.com/glasslock-process. Accessed 10 April 2020.

32. G.R.F., Alvear Flores, M. Löbbus, B. Springub B., A. FallahMehrjardi, and A. Tappe, Extraction 2018. https://doi.org/10. 1007/978-3-319-95022-8_3.

Publisher's Note Springer Nature remains neutral with regard to jurisdictional claims in published maps and institutional affiliations. 